\title{
Precursor and age-dependent differences in in vivo rates of protein synthesis in the cerebral cortex
}

Although numerous reports have appeared dealing with the effect of age on cerebral protein synthesis in vitro ${ }^{4-10,16,18}$, it is not yet firmly established that these studies faithfully reflect the in situ relationships which tune the synthetic performance of brain tissue to its maturational development. In 1966, Johnson and Luttges ${ }^{5}$ reported a rapid loss with increasing age of the ability of mouse brain cells to incorporate amino acids into protein in vitro. Further studies with ribosomal preparations ${ }^{4}$ confirmed this finding and revealed that, although the poly- $U$ directed synthesis decreased with age ${ }^{6}$, no age-dependent differences in the binding of poly-U to template RNA could account for this decrease ${ }^{7}$. Changes in the aggregation state ${ }^{17}$ and in the stability 18 of polysomes have also been reported during neural development, yet a recent study failed to note significant age-dependent modifications of the ability of brain polysomes to incorporate $\left[{ }^{3} \mathrm{H}\right]$ leucine ${ }^{18}$. Roberts et al. ${ }^{11}$ summarized the conflicting information by stating that the 'overall capacity of the brain for protein and nucleic acid synthesis varies little with age'.

Our past efforts in the field of cerebral protein synthesis have shown that free and endoplasmic reticulum-bound polysomes of the immature brain cortex actively participate in this process ${ }^{13}$ and that qualitatively different nascent polypeptides are among those formed on each of the two polysomal populations ${ }^{14}$. Most recently we also reported that in the developing brain cortex the rates of incorporation of $\left[{ }^{14} \mathrm{C}\right]-$ phenylalanine in vivo into the nascent polypeptides of nerve and glial cells ${ }^{3,12}$ are quantitatively different. In the present study we compare the formation in vivo of nascent polypeptides on the free and the endoplasmic reticulum-bound polysomes of the 7- and 18-day-old brain cortex $10 \mathrm{~min}$ after the intracerebral administration of two different precursors, $\left[{ }^{14} \mathrm{C}\right]$ leucine and $\left[{ }^{14} \mathrm{C}\right]$ phenylalanine. In order to assess fully the effects of the interplay between the type of precursor and the age of the animal on the rates of protein synthesis, we determined at each age (a) the endogenous levels of the precursors in the cortex; (b) the TCA-soluble radioactivity and the extent of the conversion of the radioactive precursors to other radioactive, TCA-soluble metabolites; (c) the specific radioactivity of the nascent proteins; (d) the pool-corrected specific radioactivity of the nascent proteins; and (e) the molar incorporation of the precursors into the proteins taken to represent the most faithful index of the actual rate of protein synthesis. We chose 7- and 18-day-old animals because at 7 days the cortex contains few if any mature glial cells, fully grown dendritic processes and synaptic contacts, while at 18 days it has abundant glial cells and a virtually complete synaptic organization and, moreover, myelination is in its final phase.

The results of the determinations are shown in Table I. It may be seen (line 1) that the cortical levels of leucine and phenylalanine changed very little between days 7 and 18 and that the levels of leucine exceeded those of phenylalanine by about $50 \%$ at both ages ${ }^{1}$. Table I also shows (line 2) that $300 \%$ more $\left[{ }^{14} \mathrm{C}\right]$ leucine and $500 \%$ more $\left[{ }^{14} \mathrm{C}\right]$ phenylalanine entered the TCA-soluble pool of the 7-day-old cortex than that of the 18-day-old cortex. Additionally, thin-layer chromatography ( $n$-butanol-glacial 


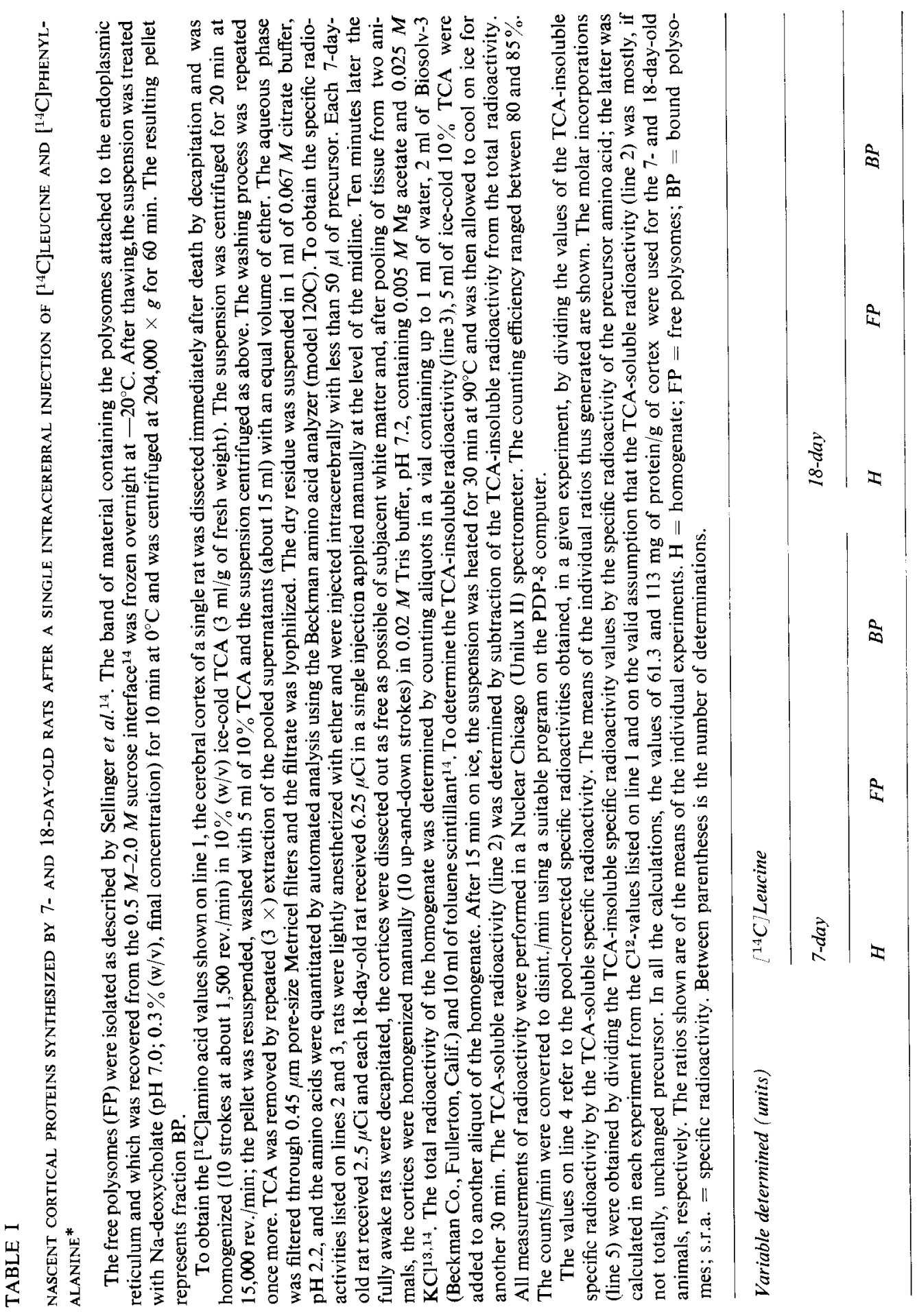




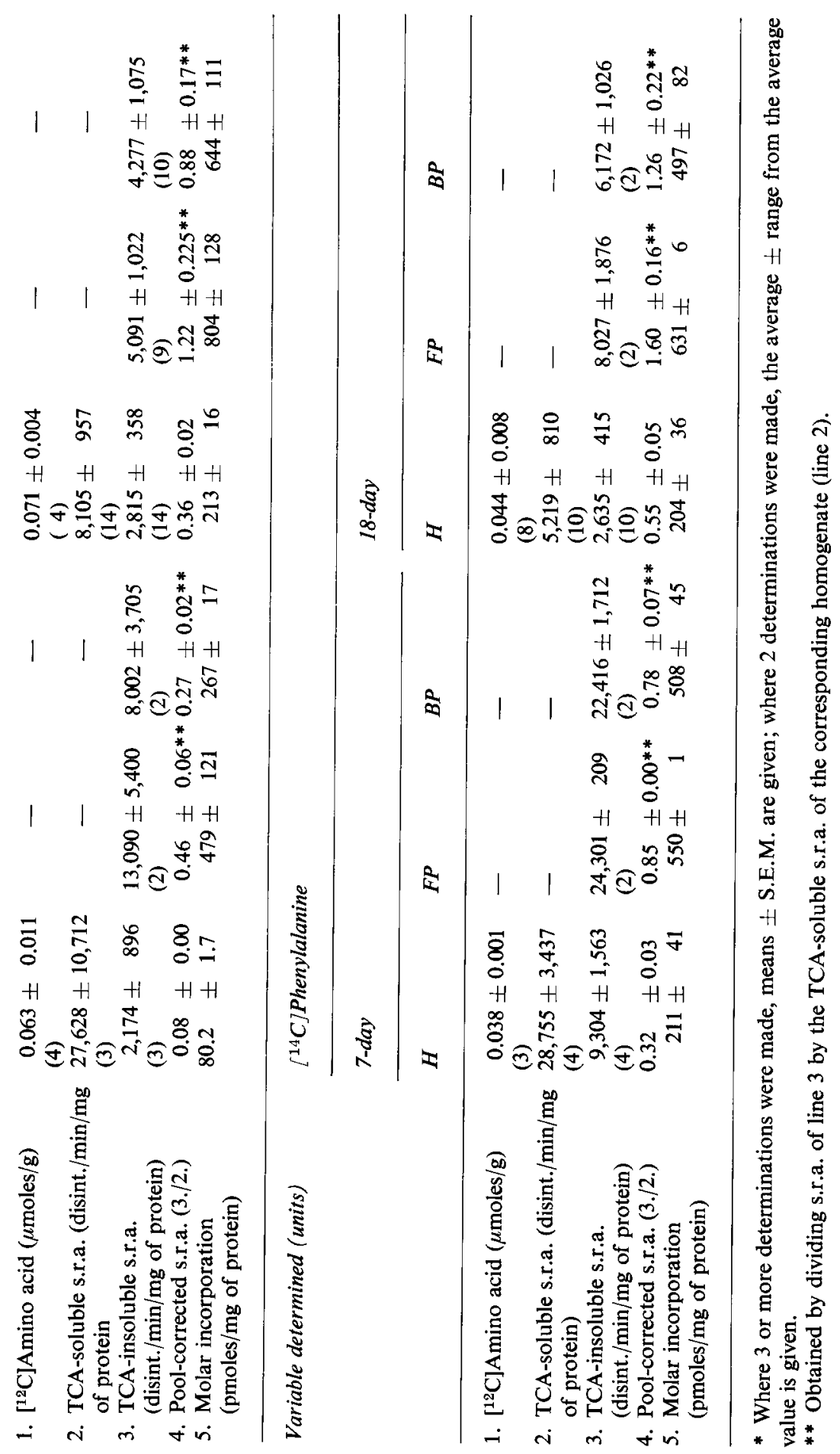


acetic acid-water, $4: 1: 5, \mathrm{v} / \mathrm{v}$ ) revealed that more than $75 \%$ of the TCA-soluble radioactivity was unchanged $\left[{ }^{14} \mathrm{C}\right]$ leucine and more than $95 \%$ was unchanged $\left[{ }^{14} \mathrm{C}\right]-$ phenylalanine. The incorporation of the [ $\left.{ }^{14} \mathrm{C}\right]$ amino acids into TCA-insoluble form is shown on line 3 of Table I, while the pool-corrected TCA-insoluble specific radioactivity (PCSA) appears on line 4. Examination of the PCSA values reveals (a) higher specific radioactivity values for the proteins of the 18- than for those of the 7-day-old cortex at all levels of c omparison (homogenate $(H)$, free polysomes (FP) and membranebound polysomes (BP)) and with both precursors and (b) higher incorporations into the free than into the membrane-bound polysome-associated nascent polypeptides, with a greater FP-BP difference for leucine than for phenylalanine. Finally, a comparison of the molar incorporations of leucine and phenylalanine into the cortical proteins (line 5), which provides the best quantitative assessment of the actual rates of protein synthesis, reveals (a) that the highest rate of incorporation was that of leucine into the nascent polypeptides associated with the free polysomes of the 18-day-old cortex and (b) that synthesis of the cerebral proteins is largely precursor- and agedependent, since the molar incorporation of leucine increased markedly between days 7 and 18 while, conversely, that of phenylalanine remained constant over the same time period.

We may compare the results of Table $I$ to the previous findings of $\mathrm{Oja}^{10}$ who showed identical molar incorporations of $\left[{ }^{3} \mathrm{H}\right]$ tyrosine into the brain proteins of 7 and 14-day-old rats in vivo, of Szijan et al. ${ }^{15}$ who reported decreasing PCSA values with age for the $\left[{ }^{14} \mathrm{C}\right]$ phenylalanine pulse-labelled cortical, cerebellar and hypothalamic, but not for the hypophyseal proteins, and of Dainat et al. ${ }^{2}$ who observed higher PCSA values for cerebellar $\left[{ }^{14} \mathrm{C}\right]$ leucine pulse-labelled proteins at 14 than at 7 days post-natally. Finally, it is worth mentioning that Zomzely et al. ${ }^{18}$ noted an agedependent difference in the partition of $\left[{ }^{3} \mathrm{H}\right]$ leucine pulse-labelled nascent proteins between the light and the heavy ribosomal aggregates and that in similar experiments in which preparations of polysomes were examined in linear sucrose density gradients, we observed a larger percentage of the $\left[{ }^{14} \mathrm{C}\right]$ leucine pulse-labelled nascent proteins to associate with the monomer + dimer + trimer region in the cortices of 18 -day-old animals than in those of 7-day old animals.

We believe that the results shown in Table I should help reconcile some of the conflicting literature findings listed above, inasmuch as they directly document the fact that brain cells utilize amino acids unequally during their maturation. We therefore recommend that future measurements of cerebral protein synthesis during development be carried out with this constraint in mind.

This research was supported by grants from the American Epilepsy Foundation (O.Z.S.), the U.S. Public Health Service (NS-06294, O.Z.S.) and the National Science Foundation (GB-21435, R.Z.). 
Mental Health Research Institute,

O. Z. SELLINGER

University of Michigan Medical Center. W. G. OHLSSON Ann Arbor, Mich. 48104 (U.S.A.)

H. H. KOHL R. ZAND*

1 BAYER, S. M., AND MCMurRay, W. C., The metabolism of amino acids in developing rat brain, J. Neurochem., 14 (1967) 695-706.

2 Dainat, J., Rebiere, A., et Legrand, J., Influence de la déficience thyroïdienne sur l'incorporation in vivo de la $\mathrm{L}-\left(\mathrm{H}^{3}\right)$-leucine dans les protéines du cervelet chez le jeune rat, $J$. Neurochem., 17 (1970) 581-586.

3 Johnson, D. E., AND Sellinger, O. Z., Protein synthesis in neurons and glial cells of the developing rat brain: an in vivo study, $J$. Neurochem., 18 (1971) 1445-1465.

4 Johnson, T. C., Cell-free protein synthesis by mouse brain during early development, J. Neurochem., 15 (1966) 1189-1194.

5 Johnson, T. C., And LutTges, M. W., The effects of maturation on in vitro protein synthesis by mouse brain cells, $J$. Neurochem., 13 (1966) 545-552.

6 LERnER, M. P., AND Johnson, T. C., Regulation of protein synthesis in developing mouse brain tissue, J. biol. Chem., 245 (1970) 1388-1393.

7 LeRner, M. P., AND Johnson, T. C., Regulation of protein synthesis in developing mouse brain tissue: in vitro binding of template RNA to brain ribosomes, $J$. Neurochem., 18 (1971) 191-201.

8 LIM, L., AND ADAMS, D. H., Microsomal components in relation to amino acid incorporation by preparations from the developing rat brain, Biochem. J., 104 (1967) 229-238.

9 Murthy, M. R. V., AND RapPoport, D. A., Biochemistry of the developing rat brain. V. Cell-free incorporation of $\mathrm{L}\left(1-\mathrm{C}^{14}\right)$ leucine into microsomal protein, Biochim. biophys. Acta (Amst.), 95 (1965) 121-131.

10 OJA, S. S., Studies on protein metabolism in developing rat brain, Ann. Acad. Sci. fenn. A, 131 (1967) 1-81.

11 Roberts, S., Zomzely, C. E., AND Bondy, S. C., Cellular aspects of neural growth and differentiation. In D. C. Pease (Ed.), UCLA Forum in Medical Sciences, Univ. of California Press, Berkeley, 1971, pp. 447-467.

12 Sellinger, O. Z., Azcurra, J. M., Johnson, D. E., Ohlsson, W. G., and Lodin, Z., Independence of protein synthesis and drug uptake in nerve cell bodies and glial cells isolated by a new technique, Nature (Lond.), 230 (1971) 253-256.

13 Sellinger, O. Z., And Ohlsson, W. G., Protein synthesis on free and endoplasmic reticulumbound polysomes of rat brain, Life Sci., 8 (1969) 1083-1088.

14 Sellinger, O. Z., Ohlsson, W. G., Frankel, A. J., Azcurra, J. M., and Petiet, P. D., A study of the nascent polypeptides synthesized on the free polyribosomes of rat brain in vivo, J. Neurochem., 18 (1971) 1243-1260.

15 Szijan, I., Kalberman, L. E., and Gomez, C. J., Hormonal regulation of brain development. IV. Effect of neonatal thyroidectomy upon incorporation in vivo of $\mathrm{L}\left(\mathrm{H}^{3}\right)$ phenylalanine into proteins of developing rat cerebral tissues and pituitary gland, Brain Research, 27 (1971) 309-318.

16 Vahvelainen, M. L., AND OJA, S. S., The uptake and incorporation into protein of $\left({ }^{3} \mathrm{H}\right)$ tyrosine by slices prepared from developing rat brain cortex, Brain Research, 13 (1969) 227-233.

17 Yamagami, S., AND Mori, K., Changes in polysomes in the developing rat brain, $J$. Neurochem., 17 (1970) 721-731.

18 Zomzely, C. E., Roberts, S., Peache, S., and Brown, D. M., Cerebral protein synthesis. III. Developmental alterations in the stability of cerebral messenger ribonucleic acid-ribosomal complexes, J. biol. Chem., 246 (1971) 2097-2103.

(Accepted September 9th, 1971)

\footnotetext{
* Biophysics Research Division, Institute of Science and Technology, University of Michigan, Ann
} Arbor, Mich., U.S.A. 